
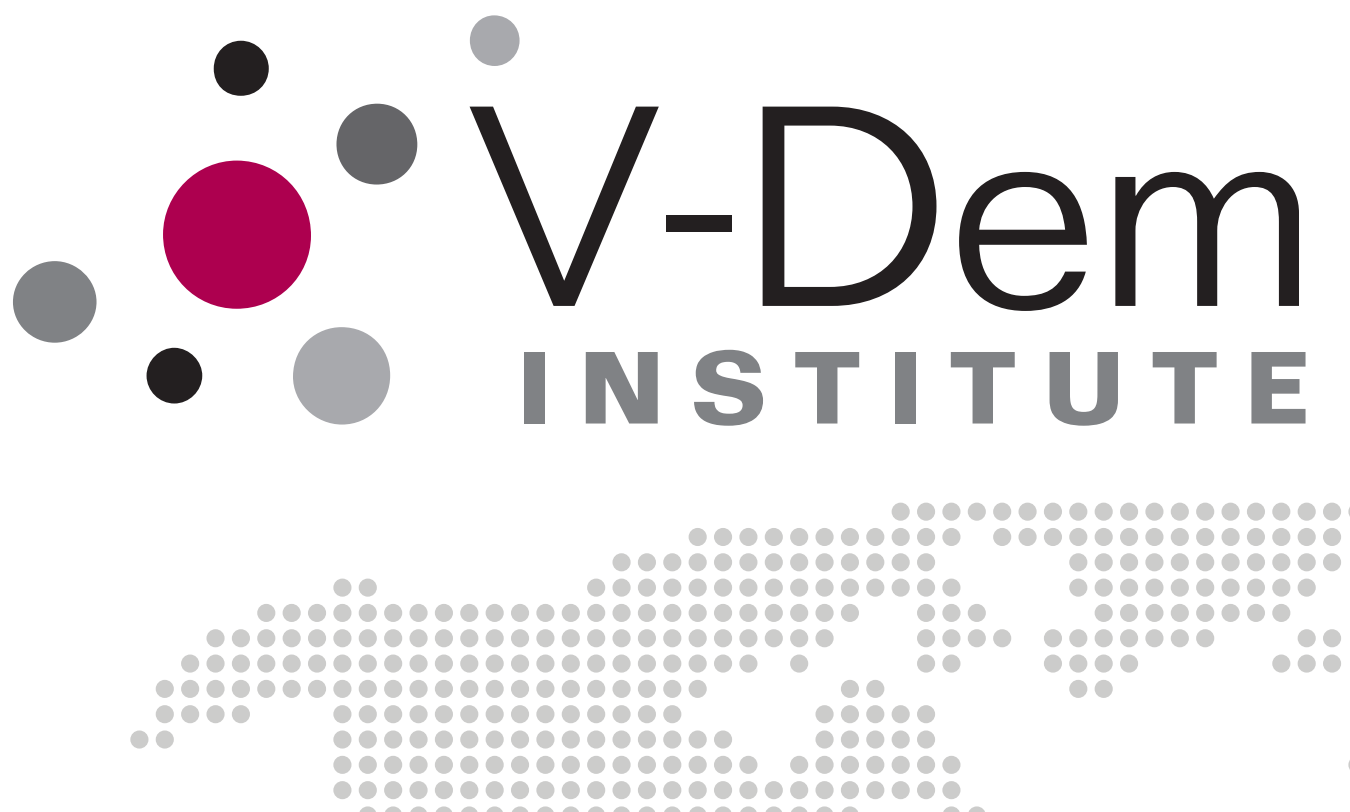

When and Where do Elections Matter? A Global Test of the Democratization by Elections Hypothesis, 1900-2012

Amanda Edgell, Valeriya Mechkova, David Altman, Michael Bernhard and Staffan I. Lindberg

000000000

0000000

000000

100000

10000

090

000

10

10

89
000

00000 6rob

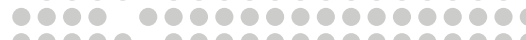

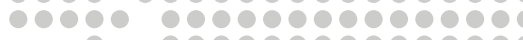
-

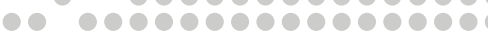

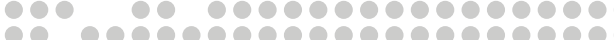

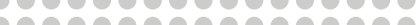
rebere

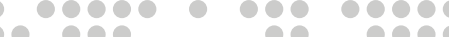

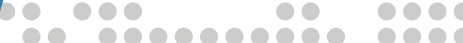

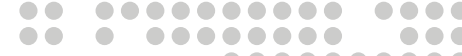

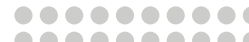

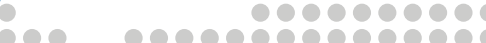

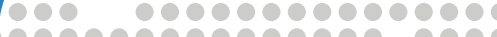
200000000000000

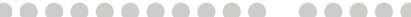

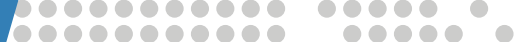

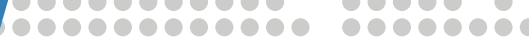

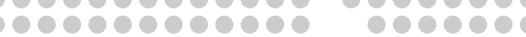
300000000000000000 00000000000000

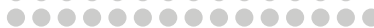

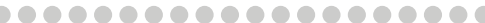

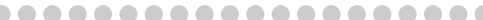
-

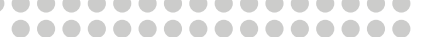
00000000000000 1900090090900 0000000000 00000000000 1000000000

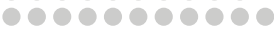

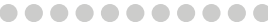
00000000000

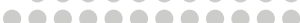

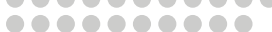

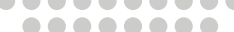
00000000 0000000 -

00000 1000 000 10

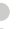
? . 20 
Varieties of Democracy (V-Dem) is a new approach to the conceptualization and measurement of democracy. It is co-hosted by the University of Gothenburg and University of Notre Dame. With a V-Dem Institute at University of Gothenburg that comprises almost ten staff members, and a project team across the world with four Principal Investigators, fifteen Project Managers, 30+ Regional Managers, 170 Country Coordinators, Research Assistants, and 2,500 Country Experts, the V-Dem project is one of the largest-ever social science research-oriented data collection programs.

Please address comments and/or queries for information to:

V-Dem Institute

Department of Political Science

University of Gothenburg

Sprängkullsgatan 19, PO Box 711

SE 40530 Gothenburg

Sweden

E-mail: contact@v-dem.net

V-Dem Working Papers are available in electronic format at www.v-dem.net.

Copyright (C) 2015 by authors. All rights reserved. 


\title{
When and Where do Elections Matter? A Global Test of the Democratization by Elections Hypothesis, 1900-2012*
}

\author{
Amanda Edgell \\ University of Florida \\ Valeriya Mechkova \\ University of Gothenburg \\ David Altman \\ Pontificia Universidad Católica de Chile \\ Michael Bernhard \\ University of Florida \\ Staffan Lindberg \\ University of Gothenburg
}

\footnotetext{
* This research project was supported by Riksbankens Jubileumsfond, Grant M13-0559:1, PI: Staffan I. Lindberg, VDem Institute, University of Gothenburg, Sweden; by Swedish Research Council, PI: Staffan I. Lindberg, V-Dem Institute, University of Gothenburg, Sweden and Jan Teorell, Department of Political Science, Lund University, Sweden; by Knut and Alice Wallenberg Foundation to Wallenberg Academy Fellow Staffan I. Lindberg, V-Dem Institute, University of Gothenburg, Sweden; by University of Gothenburg, Grant E 2013/43; by Millennium Nucleus for the Study of Stateness and Democracy in Latin America (RS130002), and the University of Florida Foundation in support of the Miriam and Raymond Ehrlich Eminent Scholar Chair in Political Science.
} 


\begin{abstract}
To date studies assessing the democratizing effects of elections have produced mixed results. While findings suggest that successive uninterrupted election cycles in a global sample (Teorell and Hadenius 2009) and within sub-Saharan Africa (Lindberg 2006, 2009) have a robust positive impact on democratization, tests in other regions have been less encouraging. In particular, negative empirical findings in Latin America (McCoy and Hartlyn 2009) and Postcommunist Europe (Kaya and Bernhard 2013) call into question whether the democratizing effect of elections is isolated to the sub-Saharan region. In addition, the hypothesis has been subject to conceptual criticism (Lust-Okar 2009). This paper poses a comprehensive and global set of tests on the democratizing effect of elections, assessing the scope of the argument both geographically and temporally. We test whether elections have a democratizing effect in specific regions, in specific time periods, and globally. In particular we assess whether the effects are largely confined to Africa, during the third wave, or if this is a more general phenomenon. We find consistent support that the reiteration of contested multiparty elections leads to the improvement of rule of law and the quality of civil rights protections.
\end{abstract}




\section{Introduction}

There are many different views on what democracy is, or ought to be. Yet, a common institutional denominator for modern democracy is elections. This is, in part, a consequence of the impracticalities of direct democracy in larger polities (Madison 1961/1789: 81-84; Jefferson 1935: 83; Mill 1958: 212-18). Elections have become the institutional key to the modern actualization of the essence of democracy: rule of the people by the people through representative government. Every modern definition of representative democracy includes contested elections as the fundamental legitimate procedure for the translation of rule by the people into workable executive and legislative power.

Now that this is more-or-less universally acknowledged, the post-Cold-War period has seen the emergence of authoritarian regimes that imitate democratic procedures without embracing their full substance. This has sparked a very different debate, which at the same time is highly consequential in terms of its policy relevance. Do elections have a causal democratizing effect, or do they, on the contrary, stabilize autocratic rule? In other words, should elections be supported as a means of democratization, or does the nearly uniform endorsement of de jure multiparty elections provide both the justification and the means for autocrats to cling to power? A number of prominent scholars in the discipline have vigorously argued both sides of the argument, thus justifying more expansive and comprehensive testing.

This paper tests the competing arguments at a global as well as regional levels and over varying time periods from 1900 to 2012. We use the Varieties of Democracy (V-Dem) dataset (version 4.3), the most comprehensive dataset on democracy ever produced (Coppedge et al. 2015b). We find strong evidence that reiterated multiparty elections brings improvement in the democratic qualities of polities both globally and in many regions of the world. In terms of variation over time we find that the democratizing effect of elections is a relatively new

phenomenon. It becomes salient during the Cold War, but has the strongest effect throughout the "third wave of democratization" or 1974 to present. Our findings also suggest some regional discrepancies. Both sub-Saharan Africa and post-Communist Eurasia show the strongest evidence of democratization by elections. Meanwhile, elections have little or no impact on civil liberties and rule of law in Asia. The results are robust to many alternative specifications including variation in sample, dependent variable, and means of estimation. As a result, they provide strong evidence in support of the democratizing effect of elections. The conclusions from this have implications for both policy and future research on democratization. 


\section{The Ambiguity of the Meaning of Elections for the Study of Regimes}

Scholars of democratization have long wrestled with the relationship between elections and democracy. In his triumphal account of the third wave of democracy, Huntington proclaims, "Elections, open, free, and fair, are the essence of democracy, the sine qua non." (1991: 9). Founding elections have often been highlighted as the end point of democratic transition, when democratically elected governments replaced authoritarian regimes (O'Donnell and Schmitter 1986, Mainwaring 1992, Bogdanor 1990). Such buoyant electoral optimism has been reeled in by calls to avoid engaging in the "fallacy of electoralism," or the error of identifying competitive elections as a sufficient condition for defining democracy (Karl 1990, Schmitter and Karl, 1991). In response, Linz and Stepan remind us that while elections are not sufficient for democracy, they are surely necessary to it (1996: 2). Przeworski (1991) adds a further caveat, pointing out that from a definitional perspective, the loser matters even more than the winner: "Democracies are systems in which parties lose elections." (10).

While academics try to make sense of the new order where a majority of states are at least minimally democratic, authoritarian leaders beset by new challenges to their authority, have come to fear that perhaps democracy is in fact becoming "the only game in town" (Linz and Stepan 1996: 8). Rather than becoming exemplars of this new spirit, autocrats try to rewrite the rules of the game. This new game is but a simulacrum of democracy, in which the kind of institutionalized uncertainty highlighted by Przeworski (1991) is subdued or at least caged. Some authoritarian incumbents learn to secure enough compliance from voters with a minimum of visible manipulation in order to dupe donors that things are heading in the democratic direction (Schedler 2009), while holding onto power with little risk of having to step down.

For a while the discipline played around with a range of different concepts - hybrid regime (Diamond 2002), semi-democracy (Diamond, Linz, and Lipset 1995), semiauthoritarianism (Ottaway 2003), or even notions with elusive real-world referents like “anocracy” (Epstein, Bates, Goldstone, Kristensen, and O’Halloran 2006). ${ }^{2}$ Schedler (2006) and Levitsky and Way (2010) resolved the ambiguity inherent in such terms when they argued that elections and even competitive elections are definitional components of not only democracies,

\footnotetext{
2 "Anocracy" is a particularly cringe-worthy neologism. It is essentially the same word as anarchy with its original Greek parts replaced with aftermarket Latin parts. The word anarchy comes to English via Latin from the Greek word anarkhos (rulerless) [an- (without) + arkhos (leader)]. Anocracy attaches that the Greek negative prefix an-on the Latin root -cracy (rule, though derived from the original Greek-kratos). How the absence of rule came to be associated with a form a rule is testimony to the powers of contemporary English to carry meaning in an extremely flexible fashion.
} 
but of newly emergent forms of authoritarianism as well. ${ }^{3}$ What differentiates competitive elections under authoritarianism is that the "playing field" is not level (or at least not as level as under democracy) and that loss by the incumbent while not precluded certainly has a lower expected probability than under democracy. This opens up a whole new perspective on regimes and regime transitions. Democratic simulation by authoritarian regimes is perhaps not a sign of democratization, but a form of adaptation making authoritarianism more durable in an era of near-hegemonic democratic enthusiasm.

\section{From Definitional to Causal}

Even though things have become more complicated definitionally, they have also become more interesting causally. If competitive elections are a necessary condition for both democracy and competitive authoritarianism, the ramifications of elections for regime outcomes become an open and interesting question. A number of authors have examined what the holding of elections means for regime outcomes. Many analysts posit reasons why authoritarian regimes might benefit from holding elections, specifically how they might stabilize authoritarian rule. Schedler (2006) was among the first to point out that the ability to hold elections and reap the legitimacy benefits they convey without much risk of relinquishing office is a net gain for authoritarian leaders. Greene (2007) argues that authoritarian one-party developmental states stabilize their regimes by using patronage from public resources to hold and win elections without resorting to high levels of fraud or repression.

Others focus less on the direct salutary effects of elections on authoritarian regimes, instead looking at how their outcome - elected legislatures - help to produce authoritarian stability. Przeworski and Gandhi (2007), for example, argue that legislatures allow authoritarian leaders to make policy concessions to or share rents with potential oppositional elites. ${ }^{4}$ They show that cases with multiple parties have shorter survival horizons, perhaps somewhat undermining their claim about elite cooptation by payoffs. Lust (2009) frames her findings from the Middle East in terms of "competitive clientelism," whereby rulers use elections to award legislative seats, which are associated with large benefits, as a means to stabilize the regime. Magaloni (2008) also highlights the role that power-sharing plays in authoritarian survival, but

\footnotetext{
${ }^{3}$ Issuing new more or less helpful labels of less-than-democratic systems of rule became a cottage industry for a while. Collier and Levitsky (1997) reportedly stopped counting at 550 different when reviewing the literature in the 1990s.

${ }_{4}^{4}$ They base their argument on the notion that there is an optimal level of party institutionalization that will promote stability for any type of regime.
} 
posited that voting and political parties are important in cementing credible commitments among the members of the elite, thus producing more durable authoritarianism. Along similar lines, Blaydes (2010) argues in the context of Egypt, that competitive elections reduce the prospects for destabilizing conflicts among key elite constituencies who compete for rents derived from the state. Finally, elections help authoritarian survival by providing information about regime popularity and satisfaction with policy outcomes. Malesky argues that even one-party elections provide some usable information to authoritarian incumbents about the popularity of local notables and may alert the central leadership to potential weaknesses outside the administrative center (2011).

In sharp contrast to the scholarship highlighting the utility of electoral institutions for authoritarian ends, another body of literature continues to support the hypothesis that the holding of competitive multiparty elections is dangerous for authoritarian regimes. One theory holds that elections, even if less than fully free and fair, inspire democratic learning and that the reiteration of multiparty elections represents a new mode of democratic transition. This was originally termed the "power of elections" (Di Palma 1993: 85) and was raised by Lindberg (2006), in his study of the third wave in Africa. Subsequent work corroborates his findings in Africa (Lindberg 2009) and, weakly, in a more global sample (Teorell and Hadenius 2009). Using an event history framework, Miller recently showed that competitive elections generally (but not necessarily linked to modern competitive authoritarian regimes) are associated with discrete transitions to democracy based on a minimal condition binary indicator of democracy (2015). However, other works raise doubts about the theory's transportability, after delivering null findings in replications for both Latin America and Postcommunist Europe (McCoy and Hartlyn 2009, Kaya and Bernhard, 2013). The validity of the causal mechanism for the Middle East and North Africa has also been questioned (Lust-Okar, 2009). Even the community of Africanists is not univocal on whether the multiparty elections of the 1990s have brought enduring democratic change. Bogaards (2013) questions Lindberg's findings based on a re-evaluation of the original evidence, while a recent extension and replication suggests that the original findings should be moderated (Morse, 2015). More generally, the third wave brought an initial burst of optimistic scholarship voicing hopes for a "second liberation" (Ayittey 1992, Hyden and Bratton 1992). This soon turned into doubts about whether these transitions represented "real" change (Carothers 1997, Josep, 1998). While scholars like Bratton (1998) argue that Africa has returned to neopatrimonial politics, others see a continuation of disorder and destructive politics (Chabal and Daloz 1999), no change at all (Akinrinade 1998), political closure (Joseph 1998), semiauthoritarianism (Carothers 1997), or elections without democracy (van de Walle 2002). 
The literature on authoritarian regime survival and replacement also presents evidence that is somewhat supportive of the idea of democratization by elections. Brownlee (2009) provides a contingent set of global findings, which generally point in the direction of the salutary effects of multiparty elections under authoritarianism for long-term democratic outcomes. His models show that while breakdown in both multiparty and other forms of authoritarianism occur at similar rates, when the former breakdown, they have a much higher propensity to become democratic (Brownlee 2009). Svolik (2012) shows that ruling authoritarian coalitions have an enhanced survival potential if they are effective in controlling the composition of the legislature. This is product of how well they can manage elections and their outcomes. His findings are thus consistent with the proposition that dominant/hegemonic multiparty authoritarianism is more stable than competitive electoral authoritarianism (190). Unlike Brownlee (2009), he does not trace what happens in terms of regime trajectory after authoritarian breakdown.

A second set of studies take the debate further by focusing on elections as junctures of enhanced threat to authoritarian regimes due to the greater uncertainty that they provoke. Howard and Roessler (2006) investigate whether multiparty elections under authoritarian conditions can turn into liberalizing junctures. They find that this is much more likely when the opposition unifies to contest elections and following periods of more intensive popular protests against authoritarian incumbents. On a similar note Bunce and Wolchik show that opposition tactics and international support were key to democratizing outcomes in the Color Revolutions (2010). Beissinger makes a similar argument but puts greater overt emphasis on tactical emulation through a diffusion mechanism (2007). Looking at the same events, Tucker (2007) presents elections, and particularly when there are perceptions of electoral fraud, as focal points allowing for the overcoming of collective action problems. Similarly, Schedler (2009) highlights the "magic" effects of popular protest on regime change following elections in autocratic regimes. While these studies are more contingent and focus on a smaller number of cases, their general thrust is the same - elections are not necessarily the culmination of democratic transition, but can be its inception as well. 


\section{Framing a More Definitive Set of Tests}

Competitive multiparty elections are thus now accepted as a defining characteristic of both democracy and competitive authoritarianism. For a large swath of the discipline this serves to address the teleological bias in the problem of never-ending transitions (Carothers, 2002), though this is much more inherent to the policy community rather than academic circles. ${ }^{5}$

Much of the research outlined above developed as a product of post-Cold-War politics, a period when discredited dictatorial alternatives incorporated multi-party elections into authoritarian systems on a scale not seen before. Previously no-party or one-party states faced pressures to open their political systems to political competition, especially those reliant on the West for developmental or financial assistance (Bratton and Van de Walle 1997, Dunning 2004). Yet, many incumbent authoritarian leaders did not relinquish power but instead tried to manage the change. ${ }^{6}$

The research that we discuss above has conceptualized these developments in two radically different ways. For Schedler, Gandhi and Przeworski, Levitsky and Way, and those who followed them, multiparty elections are an adaptation by authoritarian incumbents facing a new a set of global realities. The successful navigation of the dilemma of allowing opposition to contest elections (or the existence of representative institutions within an authoritarian framework) led to more robust and adaptable forms of authoritarianism. For the other set of authors, the emergence of multiparty elections in authoritarian states, represents a new mode of transition to democracy. Lindberg $(2006,2009)$ presents this as a protracted process where there is not a founding democratic election that punctuates a radical break between authoritarianism and democratic episodes. Reiterated elections lead to a strengthening of core democratic elements such as competition and the protection of the civil liberties, both of which are necessary to democracy. For those who theorize about the Color Revolutions, the extrication from communism did not result in democracy (though there is some ambiguity about whether these are "frozen" or "incomplete" transitions or forms of neo-authoritarianism). However, the continued holding of elections opens up periodic opportunities for the democratic opposition to press their grievances vis-à-vis the authoritarian incumbent.

\footnotetext{
${ }^{5}$ It is important to remember that the first signs of this were raised by O'Donnell's paper on "Delegative Democracy" which had circulated in conference paper form in academic circles for a year or two before it publication (1994). It is also useful in this regard to consult O'Donnell (1996) and Schneider (1995).

${ }^{6}$ Initial conceptualizations (Munck and Leff 1997) of this as a top-down mode of transition on the Spanish pattern did not last long.
} 
In this paper, we assess which of these theories has greater traction. Specifically we test if reiterated multiparty elections lead to an increase in the quality of democracy over time. Should we fail to find this it would suggest that they serve to promote an authoritarian status quo. It provides the most comprehensive test to date in terms of temporal and spatial coverage. As part of this ambition, we also seek to establish the scope conditions of the relationship between repeated multiparty competitive elections and level of democracy both temporally and regionally. Competitive authoritarianism as well as democratization via elections are third wave theories. Thus, we examine if the results hold for the third wave period and test whether this relationship can be found in earlier periods. To check for causal heterogeneity at the regional level, we retest the hypothesis within the regions for which there are previous results and beyond to see if they hold generally and for different temporal periods. Furthermore, given the rise and fall of the Arab Spring, we test if there is any traction for the theory in the Middle East and North African region.

\section{Research Design}

\section{Sample}

We test for the democratizing effect of multiparty elections in 2,032 election cycles in 156 countries from 1900 to 2012. We also run regressions on regional samples for Africa, Asia, Latin America, the Middle East and North Africa (MENA), and Postcommunist Eurasia, and we split samples along different time periods. Our unit of analysis varies by specification and includes both country-election-cycles and country-years for robustness. The largest model (global sample, country-year observations) includes 9,857 country-years.

\section{Dependent Variable}

The outcome of interest in our case is not transition to or level of democracy per se but movement towards democracy. In order to avoid tautology, we focus on processes of liberalization in key dimensions essential to democracy but distinct from elections. The rationale is that political systems already allowing multiparty elections will be differentiable into democracies and competitive authoritarian regimes by the degree to which they are strictly governed by law and the extent to which the state respects formal civil liberties. Where the playing field is uneven, we would expect incumbents to enforce the law unevenly, explicitly to their political advantage, and to disadvantage the opposition by periodically violating their basic civil rights. We constructed an index variable combining 18 indicators from the V-Dem data that 
capture rule of law and civil liberties using point estimates (Coppedge M. , et al., 2015b). The data originates from ratings provided by over 2,500 country experts. Each country-year is typically coded by a minimum of five experts aggregated to country-year ratings by a Bayesian latent-variable measurement model described in Pemstein et al. (2015). Our index is drawn from a Bayesian factor analysis model (see Appendix A1 for the variables used to compile this index). This scale of liberalization ranges from 0 to 1 and serves as our main dependent variable. Higher values on this scale indicate a higher degree of rule of law and greater civil liberties.

\section{Main Independent Variable}

The independent variable is the number of de jure multiparty elections held -Dem variables. The dataset provides a coding of electoral regimes and their interruptions (v2x_elecreg). It also includes coding for whether the number of parties that participated in each election (Coppedge et al., 2015a). ${ }^{7}$ Each count restarts from zero after a breakdown of the electoral regime. A break in multiparty electoral sequences is triggered either by an interruption in electoral regime (v2x_elecreg) or a change from multiparty elections. Because the V-Dem data only includes elections after 1900, we identified and coded all earlier election years using historical records. In total, thirty-seven countries had electoral sequences beginning prior to 1900, with the oldest beginning in the United States in 1788. To control for differences in system of government, we only count executive elections in those systems where the executive is directly elected. For systems where only the parliament is directly elected, we count elections for the legislature only (lower chamber for bicameral parliaments). For the sample included in our main models, the number of successive uninterrupted multiparty elections ranges from 0 to 57 .

Our main hypothesis is that the reiteration of elections leads to increases in the quality of democracy. Countries hold elections at different intervals and one might object that this should be accounted for. For example, the United States and Argentina hold mid-term elections to their legislatures and other countries have different term-lengths for executive and legislative office. The empirical implications of the theory we are testing, however, is that each additional election should produce positive, democratizing effects regardless of this. If the mechanism in part at least, is socialization and experiential learning where opposition parties become better at coordination, campaigning, and countering fraud; citizens learn to expect more and better rights and therefore become more likely to protest; civil society organizations and other pro-democratic bodies learn how to better advocate and challenge the regime. A greater number of elections should each have the same incremental effect and results should show up faster in countries

\footnotetext{
${ }^{7}$ Legislative elections (v2eltype_0) and executive elections (v2eltype_6) for first round elections are included. An election counts as multiparty if it scores at or above 2 on the V-Dem variable v2elmulpar_ord.
} 
holding elections more frequently. If the mechanism is in part is through elections providing a moment of mobilization and international attention when media, judges, opponents and other actors can push the boundaries and thus expand freedoms, the results are again expected with each election and should therefore materialize quicker in countries holding more frequent elections. For these reasons, we believe our specification of the main independent variable is appropriate without accounting for varying intervals between elections in different countries.

Yet, it does not make theoretical sense to expect a constant and symmetric effect of each incremental election. For example, the twentieth election in a longstanding democracy should not be expected to have the same impact as the second election in a country that just introduced competitive multiparty elections. Or to put it more concretely would we expect the same marginal effect from the election of 2014 in Sweden as the election that year in Tunisia? Given that there are likely diminishing returns and that regions have different lengths of experience with electoral democracy, we should expect to see differing results in regional studies if we model the relationship in a linear fashion. The reasoning is illustrated in the figure below that thinks about what we might reasonably expect from the different democratic experiences of Africa (AF), Latin America (LA) and Western Europe (WE).

\section{Figure 1: Regional Sample and Decreasing Returns}

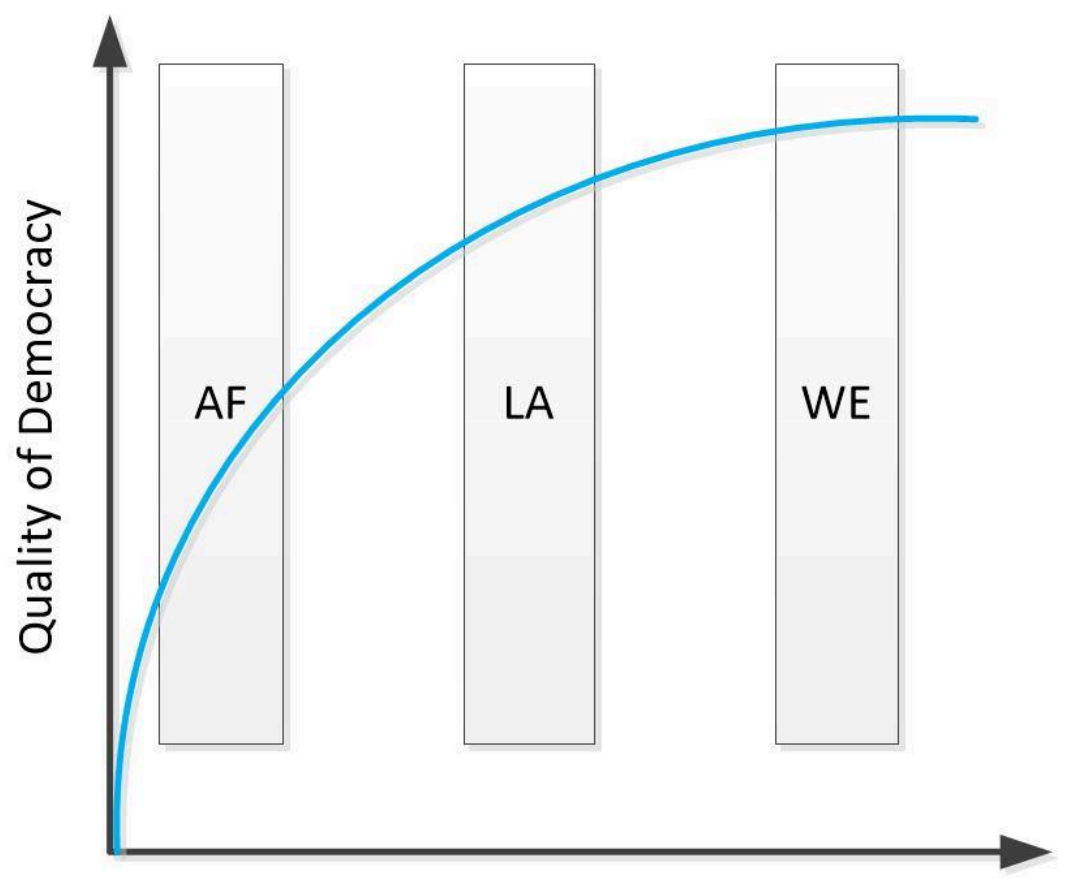

Number of Reiterated Elections 
We suspect that this issue has contributed to the disparate regional findings produced to date. They have modeled the relationship between reiterated multiparty elections and democratic qualities as a linear function. It is clear why the relationship comes out so strongly in Lindberg's African sample. Reiterated multiparty competitive elections were finally implemented widely in the 1990s and thus there is a strong positive slope because of a modest number of elections. Among the regions encompassed by the third wave, Latin America instituted multiparty competitive elections much earlier so the marginal effect of each elections would begin to diminish making the probability of significant positive outcome more difficult using linear regression. This may indeed explain why McCoy and Hartlyn (2009) did not find much support for elections as an engine of increased democratic quality in Latin America. And if one were to consider Western Europe, where many countries are highly democratic and have been for a sustained period of time, diminishing returns would make the function practically flat.

As a result, the relationship between elections and democratization should be expected to be curvilinear. While early elections will have a large effect on the level of democracy, over time this effect should diminish as a democracy is fully actualized and stabilized. This should be expected precisely because countries with higher election counts should have maximized (or nearly maximized) their level of democracy. Countries with a long history of uninterrupted multiparty elections should therefore display a smaller or nonexistent effect of an additional election compared to countries with lower election counts.

Thus we model our tests using a diminishing returns assumption by a linear-log function. Ten percent of the observations are the first election cycles that technically speaking have a zero count of successive multiparty elections. We therefore add one to each of the zero values $(x+1$, where $\mathrm{x}=0$ ). Following advice from Shadden and Zorn (2011), we then include a dummy variable to control for election cycles that were originally zeros. As a robustness check, we also include a linear model with and without long-standing, high quality democracies for our global tests. A long-standing democracy is considered any state that survives three uninterrupted election cycles at or above a score of 0.75 on the V-Dem polyarchy scale. Countries that meet this criteria drop from the data until they score below 0.75 , at which time they reenter until they meet the three democratic elections criteria again. 


\section{Control Variables}

We include four likely confounders as control variables in our models. We control for the level of development using the natural log of per capita GDP (2005 GK\$) from the previous year. To measure regime performance, we include per capita GDP growth from the previous year. Both GDP and GDP growth are measured using the estimates by Rosling, Rönnlund, and Rosling (2015). To control for oil rents, we include the previous year's oil production per capita (100,000 metric tons) based on estimates in Wimmer and Min (2006) and Ross (2013). Finally, in all random effects models, we include a control variable for the level of ethnic fractionalization as measured by Fearon and Laitin (2003). We do not include it in the fixed effects models because it is time invariant. In some of our robustness checks, we also include a time variant measure of ethnic fractionalization, developed from the CREG dataset (Nardulli et al. 2102). This measure, however, only covers the post-WWII period and thus is not included in our main models.

\section{Estimation Techniques}

We estimate cross-sectional time series models with both fixed and random effects. The primary unit of analysis is the country-election-period. We exclude observations where the country is not independent, but include pre-independence elections where they are considered integral (as coded in the V-Dem dataset) in the election count-variable. We estimate models predicting the level of protection of civil rights and the rule of law in each election period based on the number of elections the country has held, including the current one, and control variables from the country-year prior to the election. For example, for a fixed effects model, the level of protection of civil rights and rule of law observed in Uganda for 2006 is regressed on the number of successive uninterrupted multiparty elections it had held by the end of 2006 and its GDP per capita, GDP growth, and oil rents from 2005.

The model can be summarized as:

$$
y_{i t}=\alpha+\beta \ln \left(Z_{i t}\right)+\delta D_{i t}+\gamma C_{i t-1}+u_{i t}+\varepsilon_{i t}
$$

where $C_{i t-1}$ are control variables, $Z_{i t}=\left\{\begin{array}{c}x_{i t} \text { if } x_{i t}>0 \\ x_{i t}+1 \text { if } x_{i t}=0\end{array}, x_{i t}\right.$ is the number of successive multiparty elections, and $D_{i t}=\left\{\begin{array}{l}0 \text { if } x_{i t}>0 \\ 1 \text { if } x_{i t}=0\end{array}\right.$.

\footnotetext{
${ }^{8}$ Coefficients in linear-log models can be interpreted as the expected change in level of civil liberties and rule of law when the number of elections is multiplied by 2.72 (or the exponential), i.e. increased by $172 \%$. The impact of other percentage changes in the election count can be calculated as: $E(\Delta Y \mid \% \Delta X)=\hat{\beta}_{x}\left(\ln \left(\frac{(100+\% \Delta X)}{100}\right)\right)$
} 
We begin by estimating global models using all countries since 1900. These models include year fixed-effects and country-effects, both random and fixed. Then we run split-sample models by historical time period using fixed country-effects. We are particularly interested in how the effect of elections varies during the pre-Cold War, Cold War, and post-Cold War periods. We also address the importance of the third wave of democratization (1974-present) by splitting the sample of Cold War years into pre- and post-third wave models. Finally, to replicate and expand previous work in specific regions, we estimate separate fixed effects models for the entire time period and the third-wave period for sub-Saharan Africa (SSA), the Middle East and North Africa (MENA), Latin American and the Caribbean (LAC), Asia, and Post-Communist countries (PC). We do not report regional models for long-standing democratic countries (includes Western/Southern Europe, North America, New Zealand, and Australia). Estimations suggest that, as anticipated, elections are relatively unimportant for this group of consolidated democracies. They nevertheless are included in the global sample. We also conduct robustness tests using models specified with country-years, using the Freedom House civil liberties score as the outcome variable, and controlling for time-variant ethnic-fractionalization using the CREG dataset (Nardulli et al. 2012). This allows us to compare our findings to results presented in previous studies using this unit of analysis, outcome variable, and control variable.

\section{Results}

\section{Global Sample}

Table 1 presents results for the main models using the full global sample (all regions and all time). We run both fixed (1.1 and 1.2) and random country-effects (1.3 and 1.4). We present models using election periods (1.1 and 1.3) and country-years (1.2 and 1.4) as the unit of analysis. These models also control for year fixed-effects. Generally, the results are similar across specifications. All else being equal, when the number of successive multiparty elections doubles, the level of civil liberties and rule of law is expected to increase by 0.01 points (on a scale that runs from 0-1). This suggests that elections have a modest (but robust) impact on the democratic qualities of countries holding elections. 
Table 1: Fixed and Random Effects Models for Global Sample

\begin{tabular}{lcccc}
\hline & \multicolumn{2}{c}{ Fixed Effects } & \multicolumn{2}{c}{ Random Effects } \\
& $(1.1)$ & $(1.2)$ & $(1.3)$ & $(1.4)$ \\
& Election-cycle & Country-year & Election-cycle & Country-year \\
\hline Multiparty Elections (In) & $0.02^{*}$ & $0.02^{* *}$ & $0.02^{*}$ & $0.03^{* *}$ \\
& $(0.01)$ & $(0.01)$ & $(0.01)$ & $(0.01)$ \\
Zero multiparty elections & $-0.23^{* * *}$ & $-0.20^{* * *}$ & $-0.24^{* * *}$ & $-0.20^{* * *}$ \\
& $(0.03)$ & $(0.02)$ & $(0.03)$ & $(0.02)$ \\
GDP per capita (2005 Int. GK\$), & & & & \\
t-1 & 0.03 & 0.04 & $0.07^{* * *}$ & $0.05^{*}$ \\
& $(0.03)$ & $(0.02)$ & $(0.02)$ & $(0.02)$ \\
GDP per capita growth, t-1 & -0.01 & -0.05 & -0.02 & -0.06 \\
& $(0.06)$ & $(0.04)$ & $(0.06)$ & $(0.04)$ \\
Oil production per capita, t-1 & $-0.50^{* *}$ & -0.19 & $-0.65^{* *}$ & -0.25 \\
& $(0.16)$ & $(0.19)$ & $(0.21)$ & $(0.18)$ \\
Ethnic Fractionalization & & & -0.05 & -0.04 \\
& & & $(0.06)$ & $(0.07)$ \\
Constant & 0.25 & 0.21 & -0.01 & 0.12 \\
& $(0.18)$ & $(0.17)$ & $(0.12)$ & $(0.16)$ \\
R2-within & 0.48 & 0.47 & 0.48 & 0.47 \\
R2-between & 0.5 & 0.58 & 0.56 & 0.58 \\
R2-overall & 0.45 & 0.52 & 0.55 & 0.55 \\
Countries & 156 & 156 & 149 & 149 \\
Observations & 2032 & 9857 & 1984 & 9595 \\
\hline
\end{tabular}

Estimated coefficients and robust country-clustered standard errors reported. All models include year-fixed effects. ${ }^{\wedge} p<0.10,{ }^{*} p<0.05,{ }^{* *} p<0.01,{ }^{* * *} p<0.001$

The control variables largely perform as expected. The sign on the dummy variable controlling for zero multiparty elections (to control for the transformation of the zeroes to ones for the logistic transformation as suggested by Shadden and Zorn 2011) is negative, indicating that the level of protection of civil liberties and rule of law is lower prior to the holding of the first multiparty election. The log of GDP per capita is positively associated with democratic quality, but only for the random effects models. Oil production per capita, as a proxy for the negative association of the resource curse with democracy is negative and significant in electioncycle models as expected. Ethnic fractionalization (only for the RE models because the indicator in time invariant) is insignificant. Economic growth is negative, but insignificant. While this would be counterintuitive for regime survival models, we attribute this to the notion that regimes under threat of diminished support due to economic contraction, are more likely to use repressive measures thus leading to weaker protection of rule of law and civil liberties. 
As a robustness check of our model specification, we also run linear models with and without long-standing democracies. We model this relationship by rescaling the outcome variable to a 0 (low) to 100 (high). This eases interpretation of coefficients that would otherwise be very small. The results reported in Table A2 of the appendix suggest that the linear-log specification better models the behavior of the observed relationship without requiring the omission of long-standing democracies. This is evidenced by the fact that the strength of the correlation between the number of elections and the civil liberties and rule of law score increases when long-standing democracies are omitted from the sample. However, the key outcome variable is only significant for the linear model using random country-effects and fixed year effects with long-standing democracies omitted. Given the robustness of the effect of elections when using the linear-log estimation and the general theoretical rationale for doing so, it appears that the linear model fits poorly. ${ }^{9}$

\section{Variation over Time}

The literature suggests, however, that the effect of elections on democratization could be temporally bounded, particularly to the post-Cold War or third wave periods. To test this hypothesis, we present split sample models in Table 2. We estimate fixed effects models for the pre-Cold War period from 1900 to 1945 (2.1), the entire Cold War period from 1946 to 1988 (2.2), the pre-third wave portion of the Cold War from 1946 to 1973 (2.3), the Cold War portion of the third wave from 1974 to 1988 (2.4), and the post-Cold War period 1989-2012 (2.5). We do not include year fixed effects for these models due to concerns regarding the increased likelihood of biased estimates due to a large number of parameters and a small number of observations per country. Furthermore, substantively, we engage in this split sampling to gauge time effects on the basis of periodization.

The coefficient for elections during the pre-Cold War period is consistent with the full model (1.1), but fails to meet conventional levels of statistical significance ( $p>0.2)$. During the Cold War, elections have a positive, significant impact that is about 100 percent larger than the pre-Cold War period. However, this effect is primarily driven by the third wave of democratization. All else being equal, during the 14 years that the third wave overlaps with the Cold War, every time the number of successive multiparty elections doubled, the expected level

\footnotetext{
${ }_{9}^{9}$ Overall, fixed effects models using the linear-log specification also perform better according to AIC and BIC scores. The linear-log provides smaller AIC and BIC scores when compared to the linear specification, regardless of whether we use election cycle or country year as the unit of analysis.
} 
of civil liberties and rule of law increased by about 0.08 on the 0 to 1 index scale. When we take into account the entire third wave period, this effect is reduced by $27 \% .^{10}$

Table 2: Historical Trends, Global Sample

\begin{tabular}{|c|c|c|c|c|c|}
\hline & \multicolumn{5}{|c|}{ Fixed effects with country clustered robust standard errors } \\
\hline & (2.1) & (2.2) & (2.3) & $(2.4)$ & (2.5) \\
\hline & \multirow{2}{*}{$\begin{array}{r}\text { Pre-Cold War } \\
(1900-1945)\end{array}$} & \multicolumn{3}{|c|}{ Cold War } & \multirow{2}{*}{$\begin{array}{l}\text { Post-Cold War } \\
\text { (1989-2012) }\end{array}$} \\
\hline & & $\begin{array}{c}\text { Entire Period } \\
(1946-1988)\end{array}$ & $\begin{array}{c}\text { Pre-3rd Wave } \\
(1946-1973)\end{array}$ & $\begin{array}{c}\text { 3rd Wave } \\
(1974-1988)\end{array}$ & \\
\hline \multirow[t]{2}{*}{ Multiparty Elections (In) } & 0.02 & $0.04 * *$ & 0.01 & $0.11 * *$ & $0.05 * *$ \\
\hline & $(0.01)$ & $(0.01)$ & $(0.01)$ & $(0.04)$ & $(0.02)$ \\
\hline \multirow[t]{2}{*}{ Zero multiparty elections dummy } & $-0.17^{* *}$ & $-0.14 * * *$ & $-0.06^{*}$ & -0.05 & -0.08 \\
\hline & $(0.06)$ & $(0.03)$ & $(0.03)$ & $(0.04)$ & $(0.06)$ \\
\hline \multirow[t]{2}{*}{ GDP per capita (2005 Int. GK\$), t-1 } & $-0.05^{*}$ & 0.03 & $0.04^{\wedge}$ & 0.00 & 0.02 \\
\hline & $(0.03)$ & $(0.02)$ & $(0.02)$ & $(0.06)$ & $(0.03)$ \\
\hline \multirow[t]{2}{*}{ GDP per capita growth, t-1 } & 0.06 & -0.05 & -0.08 & -0.13 & 0.01 \\
\hline & $(0.07)$ & $(0.08)$ & $(0.06)$ & $(0.13)$ & $(0.09)$ \\
\hline \multirow[t]{2}{*}{ Oil production per capita, t-1 } & -4.00 & $-1.12^{* *}$ & -0.79 & 0.65 & -0.18 \\
\hline & $(5.58)$ & $(0.42)$ & $(0.69)$ & $(0.72)$ & $(0.22)$ \\
\hline \multirow[t]{2}{*}{ Constant } & $1.10 * * *$ & 0.27 & 0.24 & 0.41 & $0.44^{\wedge}$ \\
\hline & (0.19) & $(0.17)$ & $(0.15)$ & $(0.51)$ & $(0.23)$ \\
\hline R2-within & 0.28 & 0.19 & 0.07 & 0.15 & 0.09 \\
\hline R2-between & 0.20 & 0.55 & 0.49 & 0.49 & 0.51 \\
\hline R2-overall & 0.11 & 0.55 & 0.54 & 0.50 & 0.44 \\
\hline Countries & 46 & 131 & 121 & 119 & 151 \\
\hline Observations & 390 & 885 & 529 & 356 & 757 \\
\hline
\end{tabular}

Estimated coefficients and robust country-clustered standard errors reported. Unit of analysis is election cycle. ${ }^{\wedge} p<0.10,{ }^{*} p<0.05,{ }^{* *} p<0.01,{ }^{* * *} p<0.001$

Perhaps a more intuitive way to think about this is in terms of the number of elections, all else being equal, it would take for a country to move from one extreme to the other on the civil liberties and rule of law scale. Figure 2 plots the relationship between elections and improvements in the outcome variable within distinct historical periods while keeping all other covariates constant at their sample mean. During the pre-Cold-War, the pre-third-wave period of the Cold War, and the Cold War as a whole, the effects of repeated multiparty elections are more modest. In none of these samples does the reiterated impact of elections cross .75 on the protection of civil of liberties and rule of law. The period of the Cold War prior to the third wave rapidly becomes flat. Meanwhile, the effect has a more modest upward trajectory for the pre-Cold War and Cold War period as a whole (which includes the third wave observations from 1974-1989). The impact of reiterated elections for part of the third wave that overlaps with the Cold War (1974-1989) and post-Cold-War period as a whole shows a much steeper upward movement. These two periods show a much more fulsome liberalization of restrictions on civil

\footnotetext{
${ }^{10}$ Results of this model not reported here. The model for the entire third wave period (1974-2012) using fixed country-effects and including all control variables reports $\beta=0.08$; RSE $=.02$ for the election count independent variable.
} 
liberties and rule of law (scoring above 0.75). During the third wave section of the Cold War, this takes about 21 elections. After the Cold War, this takes only 10 election cycles.

\section{Figure 2. Predictions Across Historical Periods}

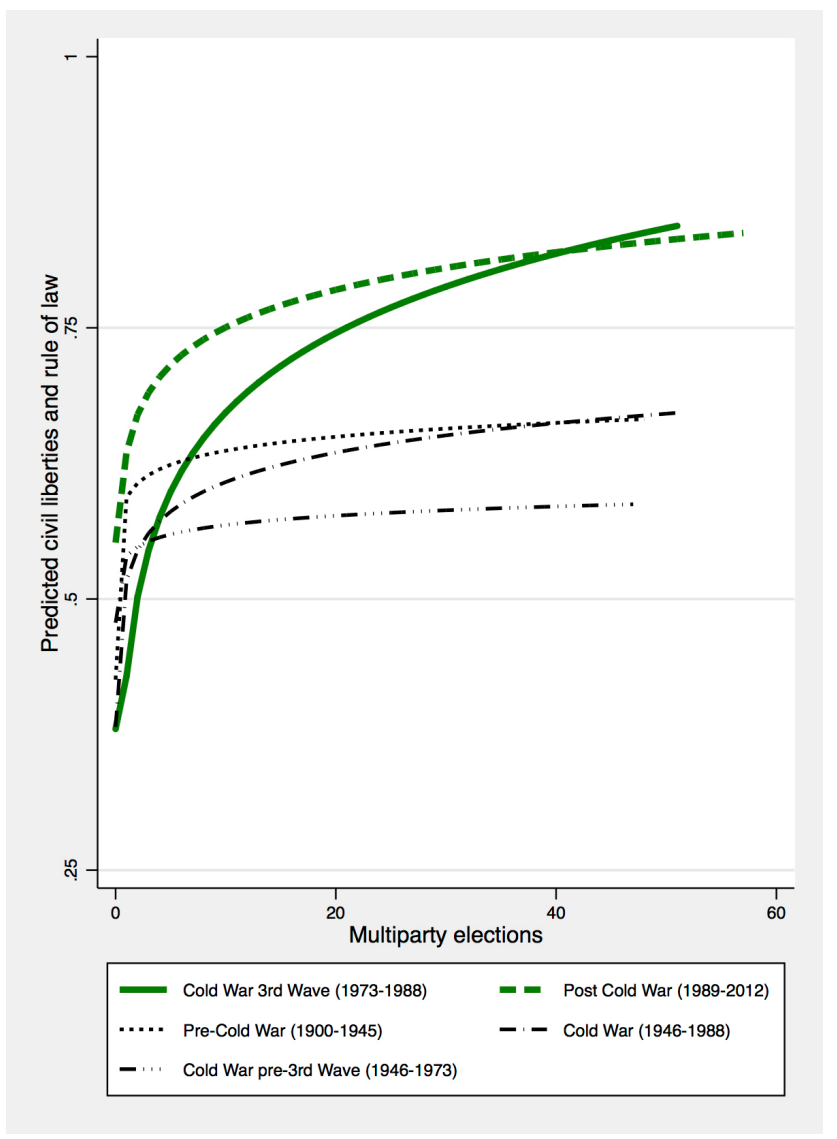

The findings are robust when controlling for a time-variant measure of ethnic fractionalization, when using country random effects, and when including the Freedom House civil liberties score as the outcome variable. In order to include ethnic fractionalization in our fixed-effects models, we compute a time variant fractionalization measure based on Alesina et al. (2003) using the CREG dataset (Nardulli et al. 2012). Similar to Fearon and Laitin's measure which is used for the random effects models, this measure estimates the odds that any two randomly selected individuals within a country will be of the same ethnicity. In Table A3 of the Appendix, we replicate our historical sample tests while including this control variable. Because the CREG dataset only covers 1946 to 2012, the ethnic fractionalization score is omitted from the pre-1946 sub-sample model. The results suggest that controlling for ethnic fractionalization has little impact on the outcome or the overall findings regarding the effect of elections. Table A4 in the Appendix reports results from historical period models when using random rather than fixed country effects. For these models, we use Fearon and Laitin's measure of ethnic 
fractionalization because of its greater coverage years. These results are also consistent with findings when using fixed effects estimation.

Finally, we test whether the results hold when using Freedom House civil liberties score rather than the V-Dem data. First, we transform the Freedom House civil liberties score into a 0-1 scale, with higher numbers indicating higher levels of democracy. This allows for comparison between the V-Dem index and the highly popular Freedom House score. As shown in Table A5 of the Appendix, results for the country fixed and random effects models suggests that the findings for the third wave period are quite similar when using the Freedom House civil liberties score as the outcome. The only major difference in the findings is that elections are only significant at the $\mathrm{p}<0.10$ level when using the fixed effects estimation for the Cold War period.

\section{Regional Variation}

The models above suggest that the onset of the third wave had an important impact on how successive uninterrupted sequences of multiparty elections affect the democratic qualities of electoral regimes. In Table 3, we test for whether this finding holds in the key geographic regions encompassed by the third wave. The results reported use fixed effects estimations with both the election-cycle and country-year as the unit of analysis. We report the findings for each region using the Freedom House civil liberties scores during the third wave as an alternative outcome variable as this was the dependent variable used some of the extant regional studies. ${ }^{11}$ The models show that elections have a positive influence on democratization in several, but not all, regions affected by the third wave.

11 The Freedom House data begin in 1973, one year prior to the onset of the third wave, so they add the full sample. Thus full sample estimations do not lead to any substantive changes and are omitted. 


\begin{tabular}{lcccccc}
\hline & \multicolumn{3}{c}{$V$-Dem Civil Liberties \& Rule of Law } & \multicolumn{2}{c}{ Freedom House Civil Liberties } \\
& Election Cycle & \multicolumn{2}{c}{ Country-Year } & Election Cycle Country-Year \\
& Full & Third & & & Third & Third \\
& Sample & Wave & Full Sample & Third Wave & Wave & Wave \\
\hline sub-Saharan Africa & $0.07^{*}$ & $0.08^{*}$ & $0.06^{*}$ & $0.10^{* *}$ & $0.06^{* *}$ & $0.08^{* * *}$ \\
& $(0.03)$ & $(0.04)$ & $(0.03)$ & $(0.03)$ & $(0.02)$ & $(0.02)$ \\
& $\mathrm{N}=369$ & $\mathrm{~N}=274$ & $\mathrm{~N}=2163$ & $\mathrm{~N}=1649$ & $\mathrm{~N}=274$ & $\mathrm{~N}=1649$ \\
Middle East \& North Africa & $0.06^{\wedge}$ & $0.07^{\wedge}$ & 0.03 & 0.03 & 0.03 & 0.03 \\
& $(0.03)$ & $(0.04)$ & $(0.03)$ & $(0.03)$ & $(0.02)$ & $(0.02)$ \\
& $\mathrm{N}=156$ & $\mathrm{~N}=92$ & $\mathrm{~N}=989$ & $\mathrm{~N}=585$ & $\mathrm{~N}=92$ & $\mathrm{~N}=585$ \\
& $0.08^{*}$ & 0.13 & 0.05 & 0.09 & 0.04 & 0.02 \\
Latin America & $(0.04)$ & $(0.08)$ & $(0.04)$ & $(0.06)$ & $(0.02)$ & $(0.02)$ \\
& $\mathrm{N}=388$ & $\mathrm{~N}=194$ & $\mathrm{~N}=1864$ & $\mathrm{~N}=935$ & $\mathrm{~N}=194$ & $\mathrm{~N}=935$ \\
Asia & 0.03 & 0.03 & 0.03 & 0.03 & 0.03 & 0.05 \\
& $(0.04)$ & $(0.04)$ & $(0.03)$ & $(0.03)$ & $(0.03)$ & $(0.03)$ \\
Post-Communist & $\mathrm{N}=267$ & $\mathrm{~N}=163$ & $\mathrm{~N}=1419$ & $\mathrm{~N}=866$ & $\mathrm{~N}=163$ & $\mathrm{~N}=866$ \\
& 0.02 & $0.08^{* *}$ & 0.03 & $0.08 * *$ & $0.11^{* * *}$ & $0.11^{* * *}$ \\
& $(0.02)$ & $(0.02)$ & $(0.02)$ & $(0.03)$ & $(0.03)$ & $(0.03)$ \\
& $\mathrm{N}=244$ & $\mathrm{~N}=159$ & $\mathrm{~N}=1074$ & $\mathrm{~N}=702$ & $\mathrm{~N}=157$ & $\mathrm{~N}=698$ \\
\hline
\end{tabular}

Estimated coefficients, country-clustered standard errors, and sample sizes reported from country-fixed effects models. All models include controls for zero multiparty counts, GDP per capita (lagged 1 year), annual GDP growth (lagged 1 year), and oil production per capita (lagged 1 year). ${ }^{\wedge} p<0.10,{ }^{*} p<0.05$, $* * p<0.01, * * * p<0.001$

For sub-Saharan Africa, the finding is robust for all eight specifications, regardless of whether they are election-cycle or country-year, third wave or not. For the Post-Communist states, the results suggest that multiparty elections have a democratizing effect only during the third wave. This contrasts with Latin America, where the full sample is significant at the $\mathrm{p}<0.05$ level but loses significance $(\mathrm{p}<0.12)$ for the third wave for the V-Dem based dependent variable using election cycle as the unit of analysis. The former is interesting in that US foreign policy towards authoritarian regimes in Latin America became less supportive beginning in 1976 with the Carter administration's focus on human rights policy. These results, however, are not robust using the Freedom House civil liberties indicator as the outcome variable or when using the country-year as the unit of analysis for the V-Dem indicator. Finally, the evidence from MENA and Asia show little to no support for the hypothesis that reiterated multiparty competitive elections lead to an improvement in democratic qualities. When using the election-cycle specification, countries in MENA experience increased democracy with more elections, but only at the $90 \%$ confidence level. This becomes insignificant in country-year and Freedom House models. In Asia, the election count variable is never significant.

As a robustness check, we also ran the same models using random rather than fixed effects. Table A6 in the Appendix provides the results for these estimations. Sub-Saharan Africa 
again stands out has showing the strongest effect of elections on democracy, although the election cycle models are only significant at the $p<0.10$ level. Results remain mixed for the Middle East and Latin America, with significant findings when using the election cycle as the unit of analysis and the V-Dem outcome variable. However, the effect of elections disappears for country-year and Freedom House outcome models. For post-communist Eurasia, the effect of elections remains primarily a post-Cold War phenomenon when using the V-Dem outcome and is robust regardless of time period for the Freedom House civil liberties score. Finally, as found with fixed effects models, Asian democracy appears unaffected by the number of elections.

With regards to the previous regional findings, we thus provide substantial corroboration of Lindberg's findings for Africa. Our mixed results for Latin America show significant but not conclusive support of the democratization-by-elections hypothesis, so we cannot fully reject McCoy and Hartlyn's findings (2009), and we duplicate their null results using Freedom House. The different results using the Freedom House and V-Dem based dependent variable could mean that the two measures are tapping into somewhat different dimensions or that the V-Dem measures' precision and methodology that minimizes Western bias in its coding, portrays a more trustworthy picture. We are inclined to believe in both, not the least because Freedom House's ratings for civil liberties are strongly correlated with their ratings for political rights $(r=0.93)$ and less so with the $\mathrm{V}$-Dem measure for civil liberties and rule of law $(\mathrm{r}=0.87)$. The very robust and positive results for the post-Communist region in the post-Cold-War period were not expected given the earlier findings of Kaya and Bernhard (2013). However, their models use very different specifications, which take into account such things as voting turnout and strength of opposition, which they were using to test a broader range of actor-centered behavior contingent theories growing out the literature on the Color Revolutions as well as the democratizing power of elections-hypothesis. However, the fixed effect models that we run here should preferably not be overburdened with controls since inclusion of too many variables can lead to hiding real effects (Achen 2005, Schrodt 2014). With the more parsimonious models here, the democratizing power of elections-hypothesis is consistently supported by empirical evidence.

The regional perspective adds further insights on the global findings. Quite clearly they are driven by some regions more than others. Asia particularly seems less prone to the democratizing effect of elections, whereas Africa and postcommunist Eurasia seem to account for the bulk of the global effect. The results for Latin America and the Middle East/North Africa fall somewhat ambiguously in the middle. 


\section{Conclusions}

The wide emergence of new forms of authoritarianism reliant on competitive multiparty elections in the period following the Cold War shook up the discipline's earlier assumptions about their role of in defining regime types. The necessity of relaxing those assumptions to make sense of competitive electoral forms of authoritarianism also meant that we needed to examine our assumptions about the ways in which countries democratize. This paper investigates whether an increasing number of multiparty competitive elections in uninterrupted sequence is associated positively with increased protection of civil liberties and the rule of law in a variety of global and regional samples over several different time periods. Overall, we produce substantial and robust findings that this is the case.

First, we show that this relationship holds over a global sample for the period 1900-2012, something only barely hinted at in the previous literature on level of democracy (Teorell and Hadenius 2009). This finding is highly congruent with Miller's findings on how multiparty elections are conducive to democratic transition using an event-history approach with a binary indicator, as opposed to our quality of democracy approach (2015). Second, we show that the effect is enhanced in certain time periods. The effect is clearly strongest during the third wave of democratization and in the post-Cold-War period. What is most interesting is that the adaptive behavior of authoritarian incumbents to a historical period of unprecedented democratic Zeitgeist was not completely effective in blunting their vulnerability to popular democratic challenges (Svolik, 2012). In their quest to remain in power by simulating democracy, they (albeit unintentionally) created a new evolutionary path to democratization through reiterated multiparty competitive elections.

Finally, we shed light on the extant regional findings which created doubt about how far the democratization through elections thesis travelled geographically. We show that the effect is most pronounced in Africa and postcommunist Eurasia. We also turn up less robust evidence of similar but much less substantial effects in Latin America as well as the Middle East and North Africa. The only region encompassed by the third wave that we do not turn up evidence for is Asia. The question of why the effect is more prominent in some areas rather than others is a compelling question, but one that must be taken up by subsequent research. All in all we can more definitely conclude that democratization through elections is not a case of African exceptionalism but a more global phenomenon. This opens up a range of intriguing new questions in untangling and explaining the temporal and regional differences we have uncovered. 


\section{References}

Achen, Christopher H. 2005. "Let's Put Garbage Can Regressions and Garbage Can Probits Where They Belong." Conflict Management and Peace Science 22, no.4: 327-339.

Akinrinade, Sola. 1998. “The Re-Democratization Process in Africa: plus cà change, plusc'est la meme." In Sola Akinrinade, and Amadu Sesay, eds., Africa in the Post-Cold War International System. London, UK: Pinter.

Ayittey, George B.N. 1992. Africa Betrayed. New York, N.Y.: St. Martins.

Beissinger, Mark R. 2007. "Structure and Example in Modular Political Phenomena: The Diffusion of Bulldozer/Rose/Orange/Tulip Revolutions." Perspectives on Politics 5, no. 2: 259-276.

Blaydes, Lisa. 2010. Elections and Distributive Politics in Mubarek's Egypt. New York, N.Y.: Cambridge University Press.

Bogaards, Matthijs. 2013. "Exchange: Reexamining African Elections.” Journal of Democracy 24, no. 4: 151-160.

Bogdanor, Vernon. 1990. "Founding Elections and Regime Change." Electoral Studies 9, no. 4: 288-94.

Bratton, Michael. 1998. "Second Elections in Africa." Journal of Democracy 9, no. 3: 51-66.

Bratton, Michael, and Nicolas van de Walle. 1997. Democratic Experiments in Africa. New York, N.Y.: Cambridge University Press.

Brownlee, Jason. 2009. "Portents of Pluralism: How Hybrid Regimes Affect Democratic Transitions." American Journal of Political Science 53, no. 3: 515-532.

Bunce, Valerie, and Sharon L. Wolchik. 2010. "Defeating Dictators: Electoral Change and Stability in Competitive Authoritarian Regime.” World Politics 62, no. 1: 43-86.

Carothers, Thomas. 1997. "Democracy without Illusions.” Foreign Affairs 76: 85-99.

- 2002. "The End of the Transitions Paradigm." Journal of Democracy 13, no. 1: 5-21.

Chabal, Patrick, and Jason-Pascal Daloz. 1999. Africa Works: Disorder as Political Instrument. Bloomington, Ind.: Indiana University Press.

Collier, David, and Steven Levitsky. 1997. "Democracy with Adjectives: Conceptual Innovation in Comparative Research." World Politics 49, no. 3: 430-451.

Coppedge, Michael, John Gerring, Staffan I..Lindberg, Jan Teorell, David Altman, Michael Bernhard, M. Steven Fish, Adam Glynn, Allen Hicken, Carl Henrik Knutsen,Kelly McMann, Daniel Pemstein, Megan Reif, Svend-Erik Skaaning, Jeffrey Staton, EitanTzelgov,Yi-ting Wang and Brigitte Zimmerman. 2015a. "Varieties of Democracy: Codebook v4." Varieties of Democracy (V-Dem) Project. At https://v- 
dem.net/media/filer_public/17/fe/17fe9954-d9aa-4961-aa73-f967929ebab9/vdem_codebook_v43.pdf, accessed July 19, 2015.

Coppedge, Michael, John Gerring, Staffan I..Lindberg, Jan Teorell, David Altman, Michael Bernhard, M. Steven Fish, Adam Glynn, Allen Hicken, Carl Henrik Knutsen,Kelly McMann, Daniel Pemstein, Megan Reif, Svend-Erik Skaaning, Jeffrey Staton, Eitan'Tzelgov,Yi-ting Wang and Brigitte Zimmerman. 2015b. Varieties of Democracy Dataset v. 4. Varieties of Democracy (V-Dem) Project.

Diamond, Larry. 2002. “Thinking About Hybrid Regimes.” Journal of Democracy 13, no. 2: 21-35. Diamond, Larry, Juan Linz, and Seymour Martin Lipset. 1995. Politics in Developing Countries. Boulder, CO., and London, UK: Lynne Reinner.

Dunning, Thad. 2004. "Conditioning the Effects of Aid: Cold War Politics, Donor Credibility, and Democracy in Africa." International Organization 58, no. 2: 409-423.

Epstein, David L., Robert Bates, Jack Goldstone, Ida Kristensen, and Sharyn O’Halloran. 2006. "Democratic Transitions." American Journal of Political Science 50, no. 3: 551-569.

Gandhi, Jennifer, and Adam Przeworski. 2007. "Authoritarian Institutions and the Survival of Autocrats." Comparative Political Studies 40, no. 11: 1279-1301.

Greene, Kenneth F. 2007. Why Dominant Parties Lose: Mexico's Democratization in Comparative Perspective. New York, N.Y.: Cambridge University Press.

Howard, Marc Morjé, and Philip G. Roessler. 2006. "Liberalizing Electoral Outcomes in Competitive Authoritarian Regimes.” American Journal of Political Science 50, no. 2: 365-381. Huntington, Samuel P. 1991. The Third Wave: Democratization in the Late Twentieth Century. Norman, OK: Oklahoma University Press.

Hyden, Goran, and Michael Bratton, eds. 1992. Government and Politics in Africa. Boulder, CO., and London, UK: Lynne Rienner.

Joseph, Richard A. 1998. “Africa, 1990-1997: From Abertura to Closure.” Journal of Democracy 9, no. 2: 3-17.

Karl, Terry L. 1990. "Dilemmas of Democratization in Latin America." Comparative Politics 23, no. 1: 1-21.

Kaya, R., and Bernhard, M. 2013. "Are Elections Mechanisms of Authoritarian Stability or Democratization? Evidence from Postcommunist Eurasia." Perspectives on Politics 11, no. 3 : 734-752.

Levitsky, Steven, and Lucan A. Way. 2010. Competitive Authoritarianism: Hybrid Regimes After the Cold War. Cambridge, UK: Cambridge University Press. 
Lindberg, Staffan I. 2006. Democracy and Elections in Africa. Baltimore: Johns Hopkins University Press.

Lindberg, Staffan I. 2009. “The Power of Elections Revisited.” In S. Lindberg, ed., Democratization by Elections: A New Mode of Transitions. Baltimore, MD.: Johns Hopkins University Press.

Linz, Juan J., and Alfred Stepan. 1996. Problems of Democratic Transition and Consolidation: Southern Europe, South America, and Post-Communist Europe. Baltimore, MD: Johns Hopkins University Press.

Lust-Okar, Ellen. 2009. "Legislative Elections in Hegemonic Authoritarian Regimes: Competitive Clientelism and Resistance to Democracy.” In S. I. Lindberg, ed., Democratization by Elections: A New Mode of Transitions. Baltimore, MD.: Johns Hopkins University Press.

Magaloni, Beatriz. 2008. "Credible Power-Sharing and Longevity of Authoritarian Rule.” Comparative Political Studies 41, no. 4-5: 715-741.

Mainwaring, Scott. 1992. "Transitions to Democracy and Democratic Consolidation: Theoretical and Comparative Issues.” In S. Mainwaring, S. Valenzuela, and G. O'Donnell, Issues in Democratic Consolidation. South Bend, Ind.: Notre Dame University Press.

Malesky, Edmund and Paul Schuler. 2011. “The Single Party Dictator's Dilemma: Information in Elections without Opposition.” Legislative Studies Quarterly 35, no. 4: 491-530.

McCoy, Jennifer L., and Jonathan Hartlyn. 2009. "The Relative Powerlessness of Elections in Latin America." In S. Lindberg, ed., Democratization by Elections: A New Mode of Transitions. Baltimore, MD.: Johns Hopkins University Press.

Miller, Michael K. 2015. "Democratic Pieces: Autocratic Elections and Democratic Development since 1815.” British Journal of Political Science 45, no. 3: 501-530.

Morse, Yonaton L. 2015. "Democratization by Elections? Revisiting Evidence from Africa." Paper presented at the Mid-West Political Science Association Annual Meeting. Chicago, IL, April 16-19.

Munck, Gerardo L., and Carol Skalnik Leff. 1997. "Modes of Transition and Democratization: South America and Eastern Europe in Comparative Perspective." Comparative Politics 29, no. 3: 343-362.

Nardulli, Peter F., Cara J. Wong, Ajay Singh, Buddy Peyton, Joseph Bajjaliegh. 2012. “The Composition of Religious and Ethnic Groups (CREG) Project.” Cline Center for Democracy, University of Illinois, Urbana-Champaign. At 
http://www.clinecenter.illinois.edu/publications/CREG-White_Paper.pdf, accessed July 19, 2015.

O'Donnell, Guillermo A. 1994. "Delegative Democracy.” Journal of Democracy 5, no. 1: 55-69.

O'Donnell, Guillermo A. 1996. "Illusions about Consolidation." Journal of Democracy 7, no. 2: 3451.

O'Donnell, Guillermo A., and Philippe C. Schmitter. 1986. “Tentative Conclusions about Uncertain Democracies.” In Guillermo A. O'Donnell, and Philippe C. Schmitter, Transitions from Authoritarian Rule Vol. 4. Baltimore, MD: Johns Hopkins University Press. Ottaway, Marina. 2003. Democracy Challenged: The Rise of Semi-Authoritarianism. Washington, D.C.: Carnegie Endowment for Peace.

Pemstein, Daniel, Eitan Tzelgov, and Yi-ting Wang. 2015. "Evaluating and Improving Item Response Theory Models for Cross-National Expert Surveys." Varieties of Democracy Institute: Working Paper Series No. 1. At https://vdem.net/media/filer_public/22/41/224180e9-464b-4da2-b067-b7d1af9b2731/vdem_working_paper_2015_1.pdf, accessed July 19, 2015.

Przeworski, Adam. 1991. Democracy and the Market. Cambridge, UK: Cambridge University Press. Rosling, Ola, Anna Rosling Rönnlund, and Hans Rosling. 2015. Gapminder Data. At http://www.gapminder.org/data/, accessed July 19, 2015.

Schedler, Andreas. 2006. The Logic of Electoral Authoritarianism. In Andreas Schedler, ed., Electoral Authoritarianism: The Dynamics of Unfree Competition. Boulder, CO and London, UK: Lynne Reiner.

Schedler, Andreas. 2009. Sources of Competition under Electoral Authoritarianism. In S. Lindberg, ed., Democratization by Elections: A New Mode of Transitions. Baltimore, MD.: Johns Hopkins University Press.

Schmitter, Philippe C., and Terry L. Karl. 1991. "What Democracy Is... and Is Not?” Journal of Democracy 2, no. 3: 75-88.

Schneider, Ben Ross. 1995. "Democratic Consolidations: Some Broad Comparisons and Sweeping Arguments." Latin American Research Review 30, no. 2: 215-234.

Schrodt, Philip A. 2014. "Seven Deadly Since of Quantitative Political Analysis." Journal of Peace Research 51, no. 2: 287-300.

Shadden, Mark, and Zorn, Christopher. 2011. "Data Transformations for Social Science Research: Theory and Best Practices.” Paper presented at the annual meeting of Society for Political Methodology, Princeton, N.J., June 28-30.

Svolik, Milan W. 2012. The Politics of Authoritarian Rule. New York: Cambridge University Press. 
Teorell, Jan, and Axel Hadenius. 2009. "Elections as Levers of Democratization: A Global Inquiry." In S. Lindberg, ed., Democratization by Elections: A New Mode of Transitions. Baltimore, MD.: Johns Hopkins University Press.

Tucker, Joshua A. 2007. "Enough! Electoral Fraud, Collective Action Problems, and PostCommunist Colored Revolutions." Perspectives on Politics 5, no. 3: 537-553.

van de Walle, Nicholas. 2002. "Elections Without Democracy: Africa's Range of Regimes." Journal of Democracy 13, no. 2: 66-80. 


\section{Appendix}

Table A1. Variables Used for Civil Liberties and Rule of Law Index

\begin{tabular}{ll}
\hline Variable Name & Description \\
\hline v2mecenefm & Government censorship effort - media \\
v2meharjrn & Harrassment of journalists \\
v2meslfcen & Media self-censorship \\
v2cldiscm & Freedom of discussion for men \\
v2cldiscw & Freedom of discussion for women \\
v2clacfree & Freedom of academic and cultural expression \\
v2clrspct & Rigorous and impartial public administration \\
v2cltrnslw & Transparent laws with predictable enforcement \\
v2clacjstm & Access to justice for men \\
v2clacjstw & Access to justice for women \\
v2cltort & Freedom from torture \\
v2clkill & Freedom from political killings \\
v2clslavem & Freedom from forced labor for men \\
v2clvlavef & Freedom from forced labor for women \\
v2clrelig & Freedom of religion \\
v2clfmove & Freedom of foreign movement \\
v2clmovem & Freedom of domestic movement for men \\
v2clmovew & Freedom of domestic movement for women
\end{tabular}

See Coppedge et al 2015b for detailed variable description. 
Table A2: Fixed and Random Effects Models for Global Sample using Linear Estimation Fixed Effects

Random Effects

$\begin{array}{llll}\text { (A2.1) } & \text { (A2.2) } & \text { (A2.3) } & \text { (A2.4) } \\ \text { With } & \text { Without } & \text { With } & \text { Without }\end{array}$

Democracies Democracies Democracies Democracies

\begin{tabular}{lcccc}
\hline Multiparty Elections & -0.04 & 0.19 & 0.07 & $0.32^{*}$ \\
& $(0.09)$ & $(0.14)$ & $(0.09)$ & $(0.14)$ \\
GDP per capita (2005 Int. GK\$), & & & & \\
t-1 & 2.20 & 0.87 & $8.01^{* * *}$ & $7.80^{* * *}$ \\
& $(2.76)$ & $(3.06)$ & $(1.66)$ & $(1.73)$ \\
GDP per capita growth, t-1 & 5.32 & 2.42 & 3.70 & 1.30 \\
& $(6.38)$ & $(7.06)$ & $(6.34)$ & $(6.95)$ \\
Oil production per capita, t-1 & $-48.14^{* *}$ & 44.24 & $-67.97^{* * *}$ & -49.49 \\
& $(16.72)$ & $(51.09)$ & $(19.48)$ & $(60.61)$ \\
Ethnic Fractionalization & & & -5.06 & -2.72 \\
& & & $(7.11)$ & $(6.99)$ \\
Constant & $35.92^{\wedge}$ & $36.09 \wedge$ & -7.47 & -9.47 \\
& $(19.11)$ & $(20.62)$ & $(12.79)$ & $(13.42)$ \\
R2-within & 0.35 & 0.34 & 0.34 & 0.33 \\
R2-between & 0.04 & 0.00 & 0.31 & 0.2 \\
R2-overall & 0.10 & 0.08 & 0.35 & 0.27 \\
Countries & 156 & 153 & 149 & 146 \\
Observations & 2032 & 1593 & 1984 & 1557 \\
\hline
\end{tabular}

Estimated coefficients and robust country-clustered standard errors reported. Outcome is the $\mathrm{V}$-Dem rule of law and civil liberties score mulitplied by 100 to ease interpretation of coefficients. All models include year fixed effects. Unit of analysis is country election cycle. ${ }^{\wedge} p<0.10,{ }^{*} p<0.05,{ }^{* *} p<0.01,{ }^{* * *} p<0.001$ 
Table A3: Historical Trends, Global Sample using CREG Ethnic Fractionalization

\begin{tabular}{|c|c|c|c|c|c|}
\hline & \multicolumn{5}{|c|}{ Fixed effects with country clustered robust standard errors } \\
\hline & (A3.1) & (A3.2) & (A3.3) & (A3.4) & (A3.5) \\
\hline & \multirow{2}{*}{$\begin{array}{r}\text { Pre-Cold War } \\
(1900-1945)\end{array}$} & \multicolumn{3}{|c|}{ Cold War } & \multirow{2}{*}{$\begin{array}{c}\text { Post-Cold War } \\
\text { (1989-2012) }\end{array}$} \\
\hline & & $\begin{array}{c}\text { Entire Period } \\
(1946-1988)\end{array}$ & $\begin{array}{c}\text { Pre-3rd Wave } \\
(1946-1973)\end{array}$ & $\begin{array}{c}\text { 3rd Wave } \\
(1974-1988)\end{array}$ & \\
\hline \multirow[t]{2}{*}{ Multiparty Elections (In) } & 0.02 & $0.04^{*}$ & 0.01 & $0.10^{*}$ & $0.05^{* * *}$ \\
\hline & $(0.01)$ & $(0.02)$ & $(0.02)$ & $(0.04)$ & $(0.02)$ \\
\hline \multirow[t]{2}{*}{ Zero multiparty elections dummy } & $-0.17 * *$ & $-0.14 * * *$ & $-0.06^{\wedge}$ & -0.04 & -0.07 \\
\hline & $(0.06)$ & $(0.04)$ & $(0.03)$ & $(0.04)$ & $(0.05)$ \\
\hline \multirow[t]{2}{*}{ GDP per capita (2005 Int. GK\$), t-1 } & $-0.05^{*}$ & 0.03 & $0.04^{\wedge}$ & 0.01 & 0.02 \\
\hline & $(0.03)$ & $(0.02)$ & $(0.02)$ & $(0.07)$ & $(0.03)$ \\
\hline \multirow[t]{2}{*}{ GDP per capita growth, $t-1$} & 0.06 & -0.06 & -0.08 & -0.18 & 0.02 \\
\hline & $(0.07)$ & $(0.08)$ & $(0.06)$ & $(0.13)$ & (0.09) \\
\hline \multirow[t]{2}{*}{ Oil production per capita, t-1 } & -4.00 & $-1.11 * *$ & -0.77 & 0.75 & -0.15 \\
\hline & (5.58) & $(0.42)$ & $(0.70)$ & $(0.71)$ & $(0.21)$ \\
\hline \multirow[t]{2}{*}{ Ethnic Fractionalization (CREG) } & & 0.00 & -0.05 & -0.02 & -0.01 \\
\hline & & $(0.02)$ & $(0.04)$ & $(0.01)$ & $(0.01)$ \\
\hline \multirow[t]{2}{*}{ Constant } & $1.10 * * *$ & 0.28 & 0.25 & 0.36 & $0.46^{*}$ \\
\hline & $(0.19)$ & (0.19) & $(0.17)$ & $(0.58)$ & $(0.23)$ \\
\hline R2-within & 0.28 & 0.19 & 0.08 & 0.12 & 0.09 \\
\hline R2-between & 0.20 & 0.53 & 0.45 & 0.49 & 0.48 \\
\hline R2-overall & 0.11 & 0.54 & 0.53 & 0.51 & 0.43 \\
\hline Countries & 46 & 124 & 116 & 112 & 142 \\
\hline Observations & 390 & 843 & 507 & 336 & 714 \\
\hline
\end{tabular}

Estimated coefficients and robust country-clustered standard errors reported. Unit of analysis is election cycle. ${ }^{\wedge} p<0.10,{ }^{*} p<0.05,{ }^{* *} p<0.01,{ }^{* * *} p<0.001$ 
Table A4: Historical Trends, Global Sample, Random Effects

\begin{tabular}{|c|c|c|c|c|c|}
\hline & \multicolumn{5}{|c|}{ Random effects with country clustered robust standard errors } \\
\hline & (A4.1) & (A4.2) & (A4.3) & (A4.4) & (A4.5) \\
\hline & \multirow{2}{*}{$\begin{array}{r}\text { Pre-Cold War } \\
(1900-1945)\end{array}$} & \multicolumn{3}{|c|}{ Cold War } & \multirow{2}{*}{$\begin{array}{l}\text { Post-Cold War } \\
(1989-2012)\end{array}$} \\
\hline & & $\begin{array}{c}\text { Entire Period } \\
(1946-1988)\end{array}$ & $\begin{array}{c}\text { Pre-3rd Wave } \\
(1946-1973)\end{array}$ & $\begin{array}{c}\text { 3rd Wave } \\
(1974-1988)\end{array}$ & \\
\hline \multirow[t]{2}{*}{ Multiparty Elections (In) } & 0.02 & $0.05^{* * *}$ & 0.02 & $0.11 * * *$ & $0.05^{* * *}$ \\
\hline & $(0.01)$ & $(0.01)$ & $(0.01)$ & $(0.02)$ & $(0.01)$ \\
\hline \multirow[t]{2}{*}{ Zero multiparty elections dummy } & $-0.20 * * *$ & $-0.15 * * *$ & $-0.09 * *$ & $-0.10 * *$ & $-0.14 * *$ \\
\hline & $(0.06)$ & $(0.03)$ & $(0.03)$ & $(0.03)$ & $(0.05)$ \\
\hline \multirow[t]{2}{*}{ GDP per capita (2005 Int. GK\$), t-1 } & -0.01 & $0.05^{* *}$ & $0.07 * * *$ & $0.06 * *$ & $0.07 * * *$ \\
\hline & $(0.03)$ & $(0.02)$ & $(0.02)$ & $(0.02)$ & $(0.02)$ \\
\hline \multirow{2}{*}{ GDP per capita growth, t-1 } & 0.04 & -0.05 & $-0.10^{\wedge}$ & -0.08 & -0.03 \\
\hline & $(0.06)$ & $(0.08)$ & $(0.06)$ & $(0.14)$ & $(0.09)$ \\
\hline \multirow[t]{2}{*}{ Oil production per capita, t-1 } & -6.94 & $-1.07 * * *$ & $-0.78 * *$ & -0.26 & -0.47 \\
\hline & $(6.26)$ & $(0.31)$ & $(0.29)$ & $(0.71)$ & $(0.41)$ \\
\hline \multirow[t]{2}{*}{ Ethnic Fractionalization (CREG) } & -0.15 & -0.07 & -0.03 & -0.04 & -0.05 \\
\hline & $(0.13)$ & $(0.07)$ & $(0.08)$ & $(0.09)$ & $(0.06)$ \\
\hline \multirow[t]{2}{*}{ Constant } & $0.73 * * *$ & 0.11 & 0.01 & -0.09 & 0.09 \\
\hline & $(0.22)$ & $(0.15)$ & $(0.13)$ & $(0.20)$ & $(0.15)$ \\
\hline R2-within & 0.27 & 0.19 & 0.07 & 0.12 & 0.07 \\
\hline R2-between & 0.44 & 0.56 & 0.49 & 0.55 & 0.53 \\
\hline R2-overall & 0.3 & 0.57 & 0.56 & 0.57 & 0.47 \\
\hline Countries & 46 & 125 & 119 & 113 & 144 \\
\hline Observations & 390 & 867 & 524 & 343 & 727 \\
\hline
\end{tabular}

Estimated coefficients and robust country-clustered standard errors reported. Unit of analysis is election cycle. ^ $p<0.10, * p<0.05, * * p<0.01, * * * p<0.001$ 
Table A5: Historical Trends, Global Sample, Freedom House Civil Liberties

\begin{tabular}{|c|c|c|c|c|}
\hline & (A5.1) & (A5.2) & (A5.3) & (A5.4) \\
\hline & \multicolumn{2}{|c|}{ Fixed Effects } & \multicolumn{2}{|c|}{ Random Effects } \\
\hline & $\begin{array}{c}\text { Cold War 3rd } \\
\text { Wave } \\
(1974-1988)\end{array}$ & $\begin{array}{l}\text { Post-Cold } \\
\text { War } \\
(1989-2012)\end{array}$ & $\begin{array}{c}\text { Cold War 3rd } \\
\text { Wave } \\
(1974-1988)\end{array}$ & $\begin{array}{c}\text { Post-Cold } \\
\text { War } \\
(1989-2012)\end{array}$ \\
\hline \multirow[t]{2}{*}{ Multiparty Elections (In) } & $0.04^{\wedge}$ & $0.05^{* * *}$ & $0.08^{* * *}$ & $0.06^{* * *}$ \\
\hline & $(0.02)$ & $(0.01)$ & $(0.02)$ & $(0.01)$ \\
\hline \multirow[t]{2}{*}{ Zero multiparty elections dummy } & 0.03 & -0.07 & $-0.10 * *$ & $-0.12^{*}$ \\
\hline & $(0.04)$ & $(0.05)$ & $(0.04)$ & $(0.05)$ \\
\hline \multirow[t]{2}{*}{ GDP per capita (2005 Int. GK\$), t-1 } & -0.07 & $0.07 * * *$ & $0.07 * * *$ & $0.09^{* * *}$ \\
\hline & $(0.05)$ & $(0.02)$ & $(0.02)$ & $(0.01)$ \\
\hline \multirow[t]{2}{*}{ GDP per capita growth, t-1 } & 0.10 & 0.12 & 0.22 & 0.07 \\
\hline & $(0.14)$ & $(0.08)$ & $(0.15)$ & $(0.08)$ \\
\hline \multirow[t]{2}{*}{ Oil production per capita, t-1 } & 0.08 & -0.18 & $-1.48^{*}$ & -0.52 \\
\hline & $(0.40)$ & $(0.26)$ & $(0.68)$ & $(0.45)$ \\
\hline \multirow[t]{2}{*}{ Ethnic Fractionalization (CREG) } & & & -0.03 & -0.05 \\
\hline & & & $(0.07)$ & $(0.05)$ \\
\hline \multirow[t]{2}{*}{ Constant } & $1.12^{* *}$ & -0.02 & -0.07 & -0.16 \\
\hline & $(0.42)$ & $(0.17)$ & $(0.16)$ & $(0.11)$ \\
\hline R2-within & 0.03 & 0.14 & 0 & 0.12 \\
\hline R2-between & 0.12 & 0.63 & 0.69 & 0.65 \\
\hline R2-overall & 0.11 & 0.56 & 0.68 & 0.58 \\
\hline Countries & 120 & 152 & 113 & 144 \\
\hline Observations & 359 & 760 & 343 & 725 \\
\hline
\end{tabular}

Estimated coefficients and robust country-clustered standard errors reported. Unit of analysis is election cycle. Freedom House civil liberties score rescaled 0-1. ${ }^{\wedge} p<0.10,{ }^{*} p<0.05,{ }^{* *}$ $\mathrm{p}<0.01, * * * \mathrm{p}<0.001$ 
Table A6: Regional Samples with Random Effects Estimation

\begin{tabular}{lccccccc}
\hline & \multicolumn{3}{c}{ V-Dem Civil Liberties \& Rule of Law } & \multicolumn{2}{c}{ Freedom House Civil Liberties } \\
& Election Cycle & \multicolumn{2}{c}{ Country-Year } & Election Cycle Country-Year \\
& Full & Third & & & Third & Third \\
& Sample & Wave & Full Sample & Third Wave & Wave & Wave \\
\hline sub-Saharan Africa & $0.06^{\wedge}$ & $0.07^{\wedge}$ & $0.06^{*}$ & $0.09^{* *}$ & $0.05^{* *}$ & $0.07^{* * *}$ \\
& $(0.03)$ & $(0.04)$ & $(0.03)$ & $(0.03)$ & $(0.02)$ & $(0.02)$ \\
& $\mathrm{N}=355$ & $\mathrm{~N}=260$ & $\mathrm{~N}=2091$ & $\mathrm{~N}=1577$ & $\mathrm{~N}=260$ & $\mathrm{~N}=1577$ \\
Middle East \& North Africa & $0.07^{* *}$ & $0.07^{*}$ & 0.03 & 0.03 & 0.04 & $0.03^{\wedge}$ \\
& $(0.02)$ & $(0.03)$ & $(0.03)$ & $(0.03)$ & $(0.02)$ & $(0.02)$ \\
& $\mathrm{N}=156$ & $\mathrm{~N}=92$ & $\mathrm{~N}=989$ & $\mathrm{~N}=585$ & $\mathrm{~N}=92$ & $\mathrm{~N}=585$ \\
Latin America & $0.08^{*}$ & $0.09^{\wedge}$ & 0.05 & 0.08 & $0.03^{\wedge}$ & 0.02 \\
& $(0.03)$ & $(0.05)$ & $(0.04)$ & $(0.06)$ & $(0.02)$ & $(0.02)$ \\
& $\mathrm{N}=381$ & $\mathrm{~N}=187$ & $\mathrm{~N}=1826$ & $\mathrm{~N}=897$ & $\mathrm{~N}=187$ & $\mathrm{~N}=897$ \\
Asia & 0.03 & 0.04 & 0.03 & 0.04 & $0.04^{*}$ & $0.05^{\wedge}$ \\
& $(0.03)$ & $(0.04)$ & $(0.03)$ & $(0.03)$ & $(0.02)$ & $(0.03)$ \\
& $\mathrm{N}=257$ & $\mathrm{~N}=154$ & $\mathrm{~N}=1370$ & $\mathrm{~N}=819$ & $\mathrm{~N}=154$ & $\mathrm{~N}=819$ \\
Post-Communist & 0.02 & $0.06^{*}$ & 0.02 & $0.07^{* *}$ & $0.09^{* * *}$ & $0.10^{* * *}$ \\
& $(0.01)$ & $(0.02)$ & $(0.02)$ & $(0.02)$ & $(0.02)$ & $(0.03)$ \\
& $\mathrm{N}=244$ & $\mathrm{~N}=159$ & $\mathrm{~N}=1074$ & $\mathrm{~N}=702$ & $\mathrm{~N}=157$ & $\mathrm{~N}=698$ \\
\hline
\end{tabular}

Estimated coefficients, country-clustered standard errors, and sample sizes reported from countryrandom effects models. All models include controls for zero multiparty counts, GDP per capita (lagged 1 year), annual GDP growth (lagged 1 year), oil production per capita (lagged 1 year), and ethnic fractionalization. ^ $p<0.10,{ }^{*} p<0.05,{ }^{* *} p<0.01, * * * p<0.001$ 